\title{
Front Matter: Volume 8684
}

, "Front Matter: Volume 8684," Proc. SPIE 8684, Design for Manufacturability through Design-Process Integration VII, 868401 (23 April 2013); doi:

$10.1117 / 12.2028890$

SPIE. Event: SPIE Advanced Lithography, 2013, San Jose, California, United States 


\section{PROCEEDINGS OF SPIE}

\section{Design for Manufacturability through Design-Process Integration VII}

Mark E. Mason

John L. Sturtevant

Editors

27-28 February 2013

San Jose, California, United States

Sponsored and Published by

SPIE 
The papers included in this volume were part of the technical conference cited on the cover and title page. Papers were selected and subject to review by the editors and conference program committee. Some conference presentations may not be available for publication. The papers published in these proceedings reflect the work and thoughts of the authors and are published herein as submitted. The publisher is not responsible for the validity of the information or for any outcomes resulting from reliance thereon.

Please use the following format to cite material from this book:

Author(s), "Title of Paper," in Design for Manufacturability through Design-Process Integration VII, edited by Mark E. Mason, John L. Sturtevant, Proceedings of SPIE Vol. 8684 (SPIE, Bellingham, WA, 2013) Article CID Number.

ISSN: 0277-786X

ISBN: 9780819494665

Published by

SPIE

P.O. Box 10, Bellingham, Washington 98227-0010 USA

Telephone +1 3606763290 (Pacific Time) · Fax +1 3606471445

SPIE.org

Copyright @ 2013, Society of Photo-Optical Instrumentation Engineers.

Copying of material in this book for internal or personal use, or for the internal or personal use of specific clients, beyond the fair use provisions granted by the U.S. Copyright Law is authorized by SPIE subject to payment of copying fees. The Transactional Reporting Service base fee for this volume is $\$ 18.00$ per article (or portion thereof), which should be paid directly to the Copyright Clearance Center (CCC), 222 Rosewood Drive, Danvers, MA 01923. Payment may also be made electronically through CCC Online at copyright.com. Other copying for republication, resale, advertising or promotion, or any form of systematic or multiple reproduction of any material in this book is prohibited except with permission in writing from the publisher. The CCC fee code is 0277-786X/13/\$18.00.

Printed in the United States of America.

Publication of record for individual papers is online in the SPIE Digital Library.

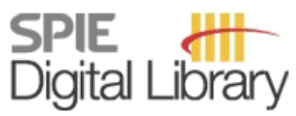

SPIEDigitalLibrary.org

Paper Numbering: Proceedings of SPIE follow an e-First publication model, with papers published first online and then in print and on CD-ROM. Papers are published as they are submitted and meet publication criteria. A unique, consistent, permanent citation identifier (CID) number is assigned to each article at the time of the first publication. Utilization of CIDs allows articles to be fully citable as soon as they are published online, and connects the same identifier to all online, print, and electronic versions of the publication. SPIE uses a six-digit CID article numbering system in which:

- The first four digits correspond to the SPIE volume number.

- The last two digits indicate publication order within the volume using a Base 36 numbering

system employing both numerals and letters. These two-number sets start with 00, 01, 02, 03, 04, $05,06,07,08,09,0 A, 0 B \ldots 0 Z$, followed by 10-1Z, 20-2Z, etc.

The CID Number appears on each page of the manuscript. The complete citation is used on the first page, and an abbreviated version on subsequent pages. Numbers in the index correspond to the last two digits of the six-digit CID Number. 


\section{Contents}

vii Conference Committee
ix Introduction

\section{SESSION 1 KEYNOTE SESSION}

868403 Design for manufacturability: a fabless perspective (Keynote Paper) [8684-2]

J. P. Cain, Advanced Micro Devices, Inc. (United States)

\section{SESSION 2 DFDP: DESIGN FOR MULTIPATTERNING}

868405 Diffraction pattern based optimization of lithographic targets for improved printability [8684-4]

S. Banerjee, K. B. Agarwal, IBM Corp. (United States)

868406 Self-aligned double patterning friendly configuration for standard cell library considering placement impact [8684-6]

J.-R. Gao, B. Yu, The Univ. of Texas at Austin (United States); R. Huang, Peking Univ. (China);

D. Z. Pan, The Univ. of Texas at Austin (United States)

868407 Evaluation of cost-driven triple patterning lithography decomposition [8684-7]

H. Tian, The Univ. of Illinois at Urbana-Champaign (United States); H. Zhang, Q. Ma,

Synopsys, Inc. (United States); M. D. F. Wong, The Univ. of Illinois at Urbana-Champaign

(United States)

\section{SESSION 3 DESIGN RULES AND ROUTING}

868408 Self-aligned double patterning compliant routing with in-design physical verification flow [8684-8]

J.-R. Gao, The Univ. of Texas at Austin (United States); H. Jawandha, P. Atkar, A. Walimbe, B. Baidya, Intel Corp. (United States); O. Rizzo, Intel Corp. (France); D. Z. Pan, The Univ. of Texas at Austin (United States)

868409 Pattern matching for identifying and resolving non-decomposition-friendly designs for double patterning technology (DPT) [8684-9]

L. T.-N. Wang, V. Dai, L. Capodieci, GLOBALFOUNDRIES Inc. (United States)

8684 OA Detailed routing with advanced flexibility and in compliance with self-aligned double patterning constraints [8684-10]

F. Nakajima, C. Kodama, Toshiba Corp. (Japan); H. Ichikawa, Toshiba Microelectronics Corp. (Japan); K. Nakayama, S. Nojima, T. Kotani, S. Mimotogi, S. Miyamoto, Toshiba Corp. (Japan) 
$8684 \mathrm{OB}$ Pioneering an on-the-fly simulation technique for the detection of layout-dependent effects during IC design phase [8684-11]

A. M. S. Tossen, A. Ramadan, Mentor Graphics Egypt (Egypt); R. F. Salem, Mentor Graphics Corp. (Canada)

\section{SESSION 4 DESIGN FOR MANUFACTURABILITY FOR DSA: JOINT SESSION WITH CONFERENCES 8680 AND} 8684

8684 OC Rethinking ASIC design with next generation lithography and process integration [8684-12] K. Vaidyanathan, R. Liu, Carnegie Mellon Univ. (United States); L. Liebmann, K. Lai, IBM Corp. (United States); A. Strojwas, L. Pileggi, Carnegie Mellon Univ. (United States)

\section{SESSION 5 OPTICAL AND DFM I: JOINT SESSION WITH CONFERENCES 8683 AND 8684}

8684 OD Enhanced spacer-is-dielectric (sid) decomposition flow with model-based verification [8684-13]

Y. Du, Synopsys, Inc. (United States) and The Univ. of Illinois at Urbana-Champaign (United States); H. Song, J. Shiely, Synopsys, Inc. (United States); M. D. F. Wong, The Univ. of Illinois at Urbana-Champaign (United States)

8684 OE Mask strategy and layout decomposition for self-aligned quadruple patterning [8684-14] W. Kang, Peking Univ. Shenzhen Graduate School (China); C. Feng, The Univ. of Michigan (United States); Y. Chen, Peking Univ. Shenzhen Graduate School (China)

8684 OF Process characteristics and layout decomposition of self-aligned sextuple patterning [8684-15]

W. Kang, Y. Chen, Peking Univ. Shezhen Graduate School (China)

8684 OG Triple patterning lithography (TPL) layout decomposition using end-cutting [8684-16] B. Yu, J.-R. Gao, D. Z. Pan, The Univ. of Texas at Austin (United States)

$8684 \mathrm{OH}$ Process window analysis of algorithmic assist feature placement options at the $2 \mathrm{X}$ nm node DRAM [8684-17]

J. Jeon, S. Kim, J. Song, C. Park, H. Yang, D. Yim, SK hynix Semiconductor Inc. (Korea, Republic of); B. Ward, Y. Zhang, K. Hooker, Synopsys, Inc. (United States); M. Do, J.-H. Choi, Synopsys Korea Inc. (Korea, Republic of); S. Jang, Synopsys, Inc. (United States)

\section{SESSION 7 DESIGN IMPLICATIONS AND VARIABILITY}

$8684 \mathrm{Ol}$ Compact modeling of fin-width roughness induced FinfET device variability using the perturbation method [8684-18]

Q. Cheng, W. Kang, Y. Chen, Peking Univ. Shenzhen Graduate School (China) 
8684 0J Understanding device impact of line edge/width roughness in frequency domain [8684-19] P. Xie, H. Ren, A. Nainani, H. Dai, C. Bencher, C. Ngai, Applied Materials, Inc. (United States)

8684 OK SRAM circuit performance in the presence of process variability of self-aligned multiple patterning [8684-20]

W. Xiao, Q. Cheng, Y. Chen, Peking Univ. Shenzhen Graduate School (China)

$8684 \mathrm{OL}$ Post-routing back-end-of-line layout optimization for improved time-dependent dielectric breakdown reliability [8684-21]

T.-B. Chan, A. B. Kahng, The Univ. of California, San Diego (United States)

8684 OM Double patterning: solutions in parasitic extraction [8684-22]

D. Petranovic, J. Falbo, N. Kurt-Karsilayan, Mentor Graphics Corp. (United States)

\section{SESSION $8 \quad$ ALGORITHMS FOR DFM}

8684 ON Model based hint for litho hotspot fixing beyond 20nm node [8684-23]

J. -H. Kang, B.-M. Kim, N. Ha, H. Choi, K. Kim, Samsung Electronics Co., Ltd. (Korea, Republic of); S. Mohamed, K. Madkour, Mentor Graphics Corp. (Egypt); W. ElManhawy, Mentor Graphics Corp. (United States); E. Lee, Mentor Graphics Corp. (Korea, Republic of); J.-M. Brunet, J. Kwan, Mentor Graphics Corp. (United States)

868400 A novel algorithm for automatic arrays detection in a layout [8684-24] M. Shafee, Mentor Graphics Corp. (Egypt); J.-W. Park, A. Aslyan, A. Torres, Mentor Graphics Corp. (United States); K. Madkour, Mentor Graphics Corp. (Egypt); W. ElManhawy, Mentor Graphics Corp. (United States)

8684 OP An automated resource management system to improve production tapeout turn-around time [8684-25]

E. Guo, Q. Liu, S. Zhu, J. Wu, Semiconductor Manufacturing International Corp. (China); J. Tsai, Mentor Graphics Corp. (United States); J. Lu, Mentor Graphics Corp. (China); M. C. Simmons, Mentor Graphics Corp. (United States)

\section{POSTER SESSION}

$8684 \mathrm{OQ}$ A novel methodology for building robust design rules by using design based metrology (DBM) [8684-5]

M. Lee, Sungkyunkwan Univ. (Korea, Republic of) and Samsung Electronics Co., Ltd. (Korea, Republic of); S. Choi, J. Choi, J. Kim, H. Sung, H. Yeo, M. Shim, G. Jin, E. Chung, Samsung Electronics Co., Ltd. (Korea, Republic of); Y. Roh, Sungkyunkwan Univ. (Korea, Republic of)

Author Index 
Proc. of SPIE Vol. $8684868401-6$

Downloaded From: https://www.spiedigitallibrary.org/conference-proceedings-of-spie on 26 Apr 2023 Terms of Use: https://www.spiedigitallibrary.org/terms-of-use 


\section{Conference Committee}

Symposium Chair

Harry J. Levinson, GLOBALFOUNDRIES Inc. (United States)

Symposium Co-chair

Mircea V. Dusa, ASML US, Inc. (United States)

Conference Chair

Mark E. Mason, Texas Instruments Inc. (United States)

Conference Co-chair

John L. Sturtevant, Mentor Graphics Corporation (United States)

Conference Program Committee

Robert Aitken, ARM Inc. (United States)

Jason P. Cain, Advanced Micro Devices, Inc. (United States)

Luigi Capodieci, GLOBALFOUNDRIES Inc. (United States)

Juan-Antonio Carballo, Broadcom Corporation (United States)

Lars W. Liebmann, IBM Corporation (United States)

Andrew R. Neureuther, University of California, Berkeley

(United States)

David Z. Pan, The University of Texas at Austin (United States)

Chul-Hong Park, Samsung Electronics Company, Ltd.

(Korea, Republic of)

Michael L. Rieger, Synopsys, Inc. (United States)

Vivek K. Singh, Intel Corporation (United States)

Chi-Min Yuan, Freescale Semiconductor, Inc. (United States)

Session Chairs

1 Keynote Session

Mark E. Mason, Texas Instruments Inc. (United States)

John L. Sturtevant, Mentor Graphics Corporation (United States)

2 DFDP: Design for Multipatterning

Lars W. Liebmann, IBM Corporation (United States)

Juan-Antonio Carballo, Broadcom Corporation (United States) 
3 Design Rules and Routing

Luigi Capodieci, GLOBALFOUNDRIES Inc. (United States)

Chi-Min Yuan, Freescale Semiconductor, Inc. (United States)

4 Design for Manufacturability for DSA: Joint Session with Conferences 8680 and 8684

Benjamen M. Rathsack, Tokyo Electron America, Inc. (United States)

Lars W. Liebmann, IBM Corporation (United States)

5 Optical and DFM I: Joint Session with Conferences 8683 and 8684

Mark E. Mason, Texas Instruments Inc. (United States)

Will Conley, Cymer, Inc. (United States)

6 Optical and DFM II: Joint Session with Conferences 8683 and 8684

Kafai Lai, IBM Corporation (United States)

John L. Sturtevant, Mentor Graphics Corporation (United States)

7 Design Implications and Variability

Robert Aitken, ARM Inc. (United States)

Michael L. Rieger, Synopsys, Inc. (United States)

8 Algorithms for DFM

Chul-Hong Park, SAamsung Electronics Company, Ltd.

(Korea, Republic of)

Jason P. Cain, Advanced Micro Devices, Inc. (United States) 


\section{Introduction}

It's been an exciting two years for me as Chair of the SPIE conference on Design for Manufacturability through Design-Process Integration (DfM-DPI). I am privileged to work with a program committee comprised of top industry contributors that have become good friends. It's an honor to work alongside of them, and this conference would certainly not exist without their ongoing efforts.

Seven years ago we started this conference based on two ideas. First, it was clear that Design for Manufacturability would be important for the semiconductor industry. Second, we recognized that process engineering (particularly lithography and related disciplines like etch and metrology) would play a key role in defining DfM tools. It's clear now that these assertions were correct.

Now in our seventh year of the DfM-DPI conference, the program committee could not be happier with the quality of work that has been submitted for publication. As usual, various experts from around the world participated representing various segments of the semiconductor industry. We are particularly excited about the quality of student papers this year, and appreciate the strong representation from Europe, Asia, and the Americas.

Our keynote speakers this year were outstanding, as is our tradition. Chris Mack lead the charge, challenging the design community to make better use of available process technology. DfM experts (and program committee members) Luigi Capodeici and Jason Cain presented the industry view of DfM from both the foundry and fabless perspective, respectively. These excellent keynotes were supported by strong technical sessions that were impressive in both their quality and breadth, covering a wide range of topics. Emphasis on double patterning implications was apparent this again year, as you might expect given continued delays and disappointments on the EUV front.

Like last year, a highlight of the event was the joint session with the Optical Lithography conference. Again leveraging the powerful overlap between computational lithography topics like OPC and SMO, two joint sessions were presented featuring papers of mutual interest to both conferences. As in previous years, the crowd was standing-room-only. Special thanks Will Conley and the Optical team for making this happen again this year.

Stated simply, the conference was very successful by any measure. As a personal note, I would like to thank the authors and conference attendees for their active participation: this conference is for you, and you make it happen.

Of course none of this would be possible without the generous support (and patience) of my co-chair (John Sturtevant of Mentor Graphics) and SPIE staff. 
Further, I deeply appreciate the efforts of the conference program committee for all their help in putting the program together and chairing sessions.

Next year, our new Chair, John Sturtevant takes the reigns. He is already working hard alongside his new co-chair, Luigi Capodieci, to put together an even better program for 2014.

We cannot wait to see you there.

Mark E. Mason John L. Sturtevant 